\title{
Formulasi Sediaan Sabun Padat Dari Ekstrak Kulit Pisang Awak (Musa Balbisiana) Secara Maserasi
}

\author{
Rosa Mardiana*, Yuniati \\ Program Studi D-III Farmasi, Akademi Farmasi YPPM Mandiri, Banda Aceh, Indonesia \\ Email: rosa29mardiana@gmail.com
}

\begin{abstract}
Abstrak-Indonesia merupakan penghasil pisang terbesar, seiring dengan tingginya produktivitas buah pisang maka jumlah limbah kulit pisangpun ikut meningkat. Saat panen pisang, bagian kulit, batang dan daun pisang (sekitar 80\%) hanya di buang tanpa pengolahan lebih lanjut. Hal inilah yang mengakibatkan potensi limbah kulit pisang yang cukup besar sehingga perlu adanya penanggulangan pada kulit pisang agar memiliki nilai baik. Kandungan di dalam kulit pisang antara lain karbohidrat, protein, lemak, kalsium, zat besi, fosfor vitamin B, C dan. Kulit pisang juga memiliki kandungan selulosa sebesar 14.4\%, Jumlah yang melimpah khususnya dari kulit pisang dapat di gunakan menjadi produk yang berdayaguna. Metode yang digunakan dalam penelitian ini menggunakan metode maserasi dimana ekstrak kulit pisang awak (Musa balbisiana) yang dibuat dalam bentuk sediaan sabun padat yang dipanaskan kemudian pemberian minyak yang langsung direaksikan dengan larutan basa pada suhu $50^{\circ} \mathrm{C}$, sehingga didapat basis sabun. Uji sediaan sabun padat yang dilakukan pada penelitian ini adalah uji organoleptik, uji pH dan uji stabilitas busa. Hasil evaluasi sediaan menunjukkan bahwa sediaan sabun padat, tidak terjadi perubahan bentuk dan bau, serta memiliki pH yang sesuai dengan standar untuk Kulit.
\end{abstract}

Kata Kunci: Kulit Pisang Awak (Musa Balbisiana), Sabun Padat, Maserasi

\begin{abstract}
Indonesia is the largest producer of bananas, along with the high productivity of bananas, the amount of banana peel waste also increases. When harvesting bananas, banana peels, stems and leaves (about 80\%) are only removed without further processing. This is what causes the potential for banana peel waste to be large enough so that it is necessary to overcome the banana peel so that it has good value. The content in banana peels include carbohydrates, protein, fat, calcium, iron, phosphorus, vitamins B, C and C. Banana peel also has a cellulose content of $14.4 \%$, an abundant amount, especially from banana peels, can be used as an efficient product. The method used in this study used the maceration method where the banana peel extract (Musa balbisiana) was made in the form of solid soap. which is heated and then the application of oil which is directly reacted with an alkaline solution at a temperature of $50^{\circ} \mathrm{C}$, so that a soap base is obtained. The solid soap preparation tests carried out in this study were organoleptic tests, $\mathrm{pH}$ tests and foam stability tests. The results of the evaluation of the preparation showed that the soap preparation was solid, there was no change in shape and odor, and had a pH that was in accordance with the standards for skin.
\end{abstract}

Keywords: Banana Peel (Musa Balbisiana), Solid Soap, Maceration

\section{PENDAHULUAN}

Indonesia merupakan penghasilan pisang terbesar, karena 50\% dari produksi pisang Asia di hasilkan oleh Indonesia dan setiap tahun produksinya makin meningkat. Hampir seluruh wilayah Indonesia termasuk daerah penghasilan pisang. Seiring dengan tingginya produktivitas buah pisang maka jumlah limbah kulit pisangpun ikut meningkat. Saat panen pisang, bagian kulit, batang dan daun pisang (80\%) hanya di buang tanpa pengolahan lanjut. Hal inilah yang mengakibatkan potensi limbah kulit pisang yang cukup besar sehingga perlu adanya penanggulangan pada kulit pisang agar memiliki nilai baik. Kulit pisang ternyata juga memiliki manfaat yang luar biasa. Beberapa kandungan di dalam kulit pisang antara lain karbohidrat, protein, lemak, kalsium, zat besi, fosfor vitamin B, C dan. Kulit pisang juga memiliki kandungan selulosa sebesar $14.4 \%$, Jumlah yang melimpah khususnya dari kulit pisang dapat di gunakan menjadi produk yang berdaya dan berguna (Rusliana, 2010). Kulit pisang mengandung senyawa alkaloid, flavonoid, saponin dan tannin yang mampu menghambat pertumbuhan bakteri. Tannin bersifat antibakteri dengan cara mempresipitasi protein. Efek antimikroba tannin melalui reaksi dengan membran sel, inaktivasi enzim, destruksi atau inaktivasi fungsi materi genetik. Antibakteri adalah zat yang dapat menggangu metabolisme mikroba yang merugikan (Madigan, 2005). Lapisan terluar tubuh manusia di sebut dengan kulit yang sangat peka berfungsi sebagai pelindung serta pertahanan utama terhadap bakteri. Salah satu pertolongan pertama untuk menjaga kesehatan kulit adalah sabun. Sabun mandi adalah produk yang di hasilkan dari reaksi antara minyak atau lemak dengan basa $\mathrm{KOH}$ atau $\mathrm{NaOH}$. Sabun mandi senyawa natrium atau kalium dengan asam lemak dari minyak nabati atau lemak hewani dan berbentuk padat, lunak atau cair, berbusa di gunakan sebagai pembersih dengan menambahkan zat pewangi dan bahan lainnya yang tidak membahayakan kesehatan (Badan Standarisasi Nasional, 1994).

Pada umumnya kulit pisang belum di manfaatkan secara nyata, hanya di buang sebagai limbah organik saja atau di gunakan sebagai makanan ternak seperti kambing, sapi, dan kerbau. jumlah kulit pisang yang cukup banyak akan memiliki nilai jual yang menguntungkan apabila bisa manfaatkan sebagai bahan baku makanan. Kandungan unsur gizi kulit pisang cukup lengkap, seperti karbohidrat, lemak, protein, kalsium, fosfor, zat besi, vitamin B, vitamin C dan air. Unsur- unsur gizi inilah yang dapat digunkan sebagai sumber energi dan antibodi bagi tubuh manusia (Munadjim, 1983: 84) 
Journal of Pharmaceutical and Health Research

Vol 2, No 1, Februari 2021, pp. 4-7

ISSN 2721-0715 (media online)

DOI 10.47065/jharma.v2i1.779

Menurut Standar Nasional (SNI) tahun 1994 sabun adalah senyawa natrium dengan asam lemak yang di gunakan sebagai pembersih tubuh, berbentuk padat, berbusa atau penambahan lain serta tidak menyebabkan iritasi pada kulit. Syarat mutu sabun padat yang di tetapkan oleh SNI yaitu sabun padat memiliki kadar air maksimal 15\%, jumlah alkali bebas maksimal 0,1\% dan jumlah asam lemak bebas kurang dari 2,5\% (Sukawaty Yullia, dkk 2016).

\section{METODOLOGI PENELITIAN}

Penelitian ini merupakan penelitian yang bersifat eksperimen yang di laksanakan di laboratorium untuk membuat formulasi sediaan sabun padat dari ekstrak kulit pisang awak (Musa balbisiana). Penelitian Formulasi Sediaan Sabun Padat dari Ekstrak Kulit Pisang awak (Musa balbisiana), dilaksanakan di Laboratorium Farmasetika Akademi Farmasi YPPM Mandiri Banda Aceh dan di Laboratorium Pendidikan Kimia FKIP Universitas Syiah Kuala Banda Aceh. Populasi dalam penelitian ini adalah kulit pisang awak (Musa balbisiana) yang di peroleh dari Penjual Pisang di Desa Lhongraya, Kecamatan Banda Raya, Provinsi Aceh. Teknik pengambilan sampel diambil secara Purposive sampling dan Metode pengolahan data secara Maserasi.

\section{HASIL DAN PEMBAHASAN}

Penelitian ini tentang Formulsi Sediaan sabun padat dari ekstrak Kulit Pisang Awak (Musa balbisiana). Sampel yang digunakan adalah kulit pisang awak (Musa balbisiana) dengan memakai metode maserasi. Metode Maserasi ini merupakan metode dingin dimana dapat menjaga stabilitas yang tidak tahan terhadap panas. Ekstrak kulit pisang awak yang di lakukan dengan perbandingan 1:10 menggunakan metode maserasi. Kulit pisang awak (Musa balbisiana) di lakukan maserasi dengan pelarut etonol $96 \%$ untuk memudahkan menguap sehingga baik di gunakan sebagai pelarut ekstrak dan etanol juga memiliki senyawa organik yang tersusun dari unsur-unsur karbon, hidrogen dan oksigen. Sediaan kulit pisang awak yang diperoleh maserasi di vakum dengan vaccum evaporator akan mendapatkan ekstrak pekat.

Pembuatan sabun padat pada penelitian ini menggunakan basa Natrium Hidroksida $(\mathrm{NaOH})$ agar sabun dihasilkan padat. Formula yang di gunakan pada proses pembuatan sabun dari ekstrak kulit pisang awak dengan jumlah variasi minyak kelapa $15 \mathrm{~g}$, minyak zaitun $10 \mathrm{~g}$, minyak sawit $15 \mathrm{~g}$, asam stearat $7 \mathrm{~g}, \mathrm{NaOH} \mathrm{8,9} \mathrm{g,} \mathrm{pewangi} 1 \mathrm{ml}$ dan aquadest 20 g. Formula sabun padat dari Ekstrak kulit pisang awak (Musa balbisina)

Tabel 1. Formulasi Sabun Padat

\begin{tabular}{llll}
\hline No & \multicolumn{1}{c}{ Bahan } & \multicolumn{1}{c}{$\mathrm{F}_{0}(\mathrm{gr})$} & \multicolumn{1}{c}{$\mathrm{F}_{1}(\mathrm{gr})$} \\
\hline 1 & Ekstrak Kulit Pisang Awak & - & $2 \mathrm{gr}$ \\
2 & Minyak Zaitun & $10 \mathrm{~g}$ & $10 \mathrm{~g}$ \\
3 & VCO & $15 \mathrm{~g}$ & $15 \mathrm{~g}$ \\
4 & Minyak Sawit & $15 \mathrm{~g}$ & $15 \mathrm{~g}$ \\
5 & NaOH & $8,9 \mathrm{~g}$ & $8,9 \mathrm{~g}$ \\
6 & Pewangi & $1 \mathrm{ml}$ & $1 \mathrm{ml}$ \\
7 & Asam Stearate & $7 \mathrm{~g}$ & $7 \mathrm{~g}$ \\
8 & Aquadest & $20 \mathrm{~g}$ & $20 \mathrm{~g}$ \\
\hline
\end{tabular}

Sumber: Hasil Penelitian, 2020

\subsection{Hasil Uji Organoleptik}

Evaluasi yang dilakukan pada pengujian organoleptik meliputi warna dan aroma/bau dari sediaan. Sabun padat yang harus dipenuhi adalah memiliki bentuk padat, warna dari sediaan homogen dan baunya tidak tengik. Warna yang di hasilkan merupakan warna campuran dari minyak dan $\mathrm{NaOH}$ yang berwarna putih dan ekstrak kulit pisang awak berwarna krim. Hasil pengujian bentuk, warna dan bau yang di lakukan pada hari ke 1 dan hari ke 7 dapat dilihat pada tabel sebagai berikut:

a.Bentuk Sediaan Sabun Padat

Tabel 2. Hasil Sediaan Bentuk Sabun Padat

\begin{tabular}{cccc}
\hline \multirow{2}{*}{ No } & Waktu & \multicolumn{2}{c}{ Sediaan sabun Padat } \\
& Pengamatan & $\mathrm{F}_{0}$ & $\mathrm{~F}_{1}$ \\
\hline 1 & Hari ke-1 & Padat & Padat \\
2 & Hari ke-7 & Padat & Padat \\
\hline
\end{tabular}

Sumber: Hasil Penelitian, 2020 
Journal of Pharmaceutical and Health Research

Vol 2, No 1, Februari 2021, pp. 4-7

ISSN 2721-0715 (media online)

DOI 10.47065/jharma.v2i1.779

b. Warna

Tabel 3. Hasil Warna Sabun Padat

\begin{tabular}{cccc}
\hline \multirow{2}{*}{ No } & Waktu & \multicolumn{2}{c}{ Sediaan sabun Padat } \\
& Pengamatan & $\mathrm{F}_{0}$ & $\mathrm{~F}_{1}$ \\
\hline 1 & Hari ke-1 & Cream & Cream \\
2 & Hari ke-7 & Cream & Cream \\
\hline
\end{tabular}

Sumber: Hasil Penelitian, 2020

c. Aroma/Bau

Tabel 4. Hasil Aroma/Bau Sabun Padat

\begin{tabular}{cccc}
\hline \multirow{2}{*}{ No } & Waktu & \multicolumn{2}{c}{ Sediaan sabun Padat } \\
& Pengamatan & $\mathrm{F}_{0}$ & $\mathrm{~F}_{1}$ \\
\hline 1 & Hari ke-1 & Aroma Pisang & Aroma Pisang \\
2 & Hari ke-7 & Aroma Pisang & Aroma Pisang \\
\hline
\end{tabular}

Sumber: Hasil Penelitian, 2020

\section{$3.2 \mathrm{Uji}$ pH}

Sabun pada umumnya mempunyai pH sekitar 9-10. Menurut (Sausan,2018) pH sabun yang relatif aman adalah 9-11 dan $\mathrm{pH}$ indikator potensi iritasi pada sabun. $\mathrm{pH}$ sabun yang relatif basa dapat membantu kulit untuk membuka pori-porinya kemudian busa dari sabun mengikat sabun dan kotoran lain yang menempel di kulit (Sausan,2018). Nilai pH di tentukan dengan menggunakan Stik pH. Hasil Percobaan yang telah dilakukan, dapat dilihat pada tabel 4.5 Sebagai berikut:

Tabel 5. Hasil Uji pH

\begin{tabular}{cccc}
\hline \multirow{2}{*}{ No } & \multirow{2}{*}{ Waktu } & \multicolumn{2}{c}{ Waktu Pengamatan Uji } \\
& Pengamatan & $\mathrm{F}_{0}$ & $\mathrm{pH}$ \\
& & 10 & $\mathrm{~F}_{1}$ \\
\hline 1 & Hari ke-1 & 10 & 9 \\
2 & Hari ke-7 & 10 & 9 \\
\hline
\end{tabular}

\subsection{Hasil Stabilitas Busa}

Data hasil uji tinggi busa dilihat pada tabel berikut ini:

Tabel 6. Hasil Stabilitas Busa

\begin{tabular}{lcc}
\hline Percobaan Tinggi Busa & Formulasi 0 & Formulasi 1 \\
\cline { 2 - 3 } & $3,7 \mathrm{~cm}$ & $7 \mathrm{~cm}$ \\
\hline
\end{tabular}

Hasil percobaan tinggi busa sediaan menunjukkan bahwa pada tinggi busa akan memiliki persyaratan tinggi busa yaitu 1,3-22 cm. Hasil uji pada percobaan busa pada formula 0 memiliki yaitu $3,5 \mathrm{~cm}$ dan pada formula I memiliki yaitu $7 \mathrm{~cm}$.

\section{KESIMPULAN}

Dari hasil penelitian tentang formulasi sediaan sabun padat dari ekstrak Kulit Pisang Awak (Musa balbisiana) dengan sampel yang digunakan adalah kulit pisang awak (Musa balbisiana) dan menggunakan metode maserasi menghasilkan menghasilkan kesimpulan bahwa tinggi busa sediaan menunjukkan bahwa sediaan sabun padat, tidak terjadi perubahan bentuk dan bau, serta memiliki pH yang sesuai dengan standar untuk Kulit.

\section{DAFTAR PUSTAKA}

Rusliana, (2010) Formulasi Dan Evaluasi Sabun Padat Antioksidan Ekstrak Maserasi Kulit Buah Pisang Kepok (Musa normalis L). Jurnal Para Pemikir. Tegal

Madigan, (2005) Uji Aktivitas Antibakteri Limbah Kulit Pisang Kepok (Musa balbisiana), Kulit Pisang Uli (Musa Paradisiana Sapientum) Dan Kulit Pisang Nangka (Musa sp L) : Bogor. Vol.6. No.2.

Munadjim, (2014) Pemanfaatan Dan Pengolahan Limbah Kulit Pisang Menjadi Permen Kulit Pisang Yang Berkhasiat Antidepresi Dalam Upaya Pemberdayaan Kesehatan Dan Perekonomian Masyarakat. Cianjur. Vol. 3 No. 1. Hal 5-8

Rusliana, (2010) Formulasi Dan Evaluasi Sabun Padat Antioksidan Ekstrak Maserasi Kulit Buah Pisang Kepok (Musa normalis L). Jurnal Para Pemikir. Tegal

SNI, (1994) Pembuatan Sabun Mandi Padat Dari VCO Yang Mengandung Karotenoid Wortel. Vol. 1. No. 1. Hal 20-23. 
Journal of Pharmaceutical and Health Research

Vol 2, No 1, Februari 2021, pp. 4-7

ISSN 2721-0715 (media online)

DOI 10.47065/jharma.v2i1.779

Sausan Doni, (2018) Formulasi Sabun Padat Kaolin dengan Variasi Konsentrasi Minyak Kelapa dan Asam Stearat Sebagai Penyuci Najis Mughalladzah. Program Studi Farmasi, Jakarta.

Sukawaty Yullia, (2016) Formulasi Sediaan Sabun Mandi Padat Ekstrak Etanol Umbi Bawang Tiwai (Eleutherine bulbosa M.) Urb): Jurnal Media Farmasi. Samarinda. Vol. 13 No. 1. Hal 14-22. 